\title{
Familial Adenomatous Polyposis Registry in Czech Republic - History, Present and Future
}

Jiři Cyrany*

familial adenomatous polyposis; registry

AUTHOR AFFILIATIONS

2nd Department of Internal Medicine - Gastroenterology, Charles University, Medical Faculty and University Hospital Hradec Králové, Czech Republic

* Corresponding author: 2nd Department of Internal Medicine - Gastroenterology, University Hospital Hradec Králové, Sokolská 581, 50005 Hradec Králové; e-mail: jiri.cyrany@fnhk.cz

Received: 21 December 2016

Accepted: 25 April 2017

Published online: 7 June 2017

Acta Medica (Hradec Králové) 2017; 60(1): 55-57

https://doi.org/10.14712/18059694.2017.51

(c) 2017 The Author. This is an open-access article distributed under the terms of the Creative Commons Attribution License (http://creativecommons.org/licenses/by/4.0), which permits unrestricted use, distribution, and reproduction in any medium, provided the original author and source are credited. 
FAMILIAL ADENOMATOUS POLYPOSIS INTRODUCTION

Familial adenomatous polyposis (FAP) is a hereditary neoplastic syndrome caused by mutation in genes APC (adenomatous polyposis coli) or MUTYH (mutY DNA glykosylase) - numerous colorectal adenomas are the main phenotypic feature. Although the disease is responsible for less than $1 \%$ of colorectal cancer cases in overall population, affected individual is exposed to almost absolute risk of colorectal cancer and various extracolonic neoplasias and other manifestations, frequently in young age. Prophylactic colectomy remains the only way to reduce mortality for colorectal cancer, despite some effect of chemoprophylaxis (e.g. coxibs). The person must undergo lifelong follow-up including endoscopic examinations to control risk of extracolonic malignancies, especially duodenal and desmoid tumours. Disease and/or prophylactic operation have a significant impact on patient's quality of life. Affected individual and his/her families need specialized care based on interdisciplinary cooperation organized within regional, national and international networks.

\section{HISTORY AND SIGNIFICANCE OF FAP REGISTRATION}

First FAP register was founded in St. Mark's hospital, London by pathologist Cuthbert Dukes, surgeon J. P. Lockhart-Mummery and assistant H.J. R. Bussey (1). According to systematic review of studies, registration and screening result in reduction of colorectal cancer incidence and mortality in patients with FAP (and Lynch syndrome) (2). FAP registries provide many additional benefits: organisational, patient-focused and research-focused. Majority of western countries runs its own FAP registries. InSiGHT (International Society for Gastrointestinal Hereditary Tumours) currently covers these activities on international bases (3).

\section{HISTORY OF FAP REGISTRATION IN CZECH REPUBLIC}

Assoc. prof. Václav Jirásek is the highly recognized nestor of FAP registration in Czech Republic and ran FAP register in General University Hospital in Prague for ages. Formal working group for FAP in Czech Republic was founded in May 2006 by prof. Milan Lukáš and Aleš Novotný, M.D. The working group consisted from predominantly gastroenterologists, but also surgeons, pathologists and geneticists. Network of 11 centres was established. FAP register was prepared by this group and opened at the beginning of 2008 - more than 80 polyposis cases were enrolled altogether, although only one centre was active since $2011-45$ polyposis cases were registered till the end of 2015 from this centre in Faculty hospital in Hradec Králové. Members of FAP working group regularly presented papers on national congresses: Hereditary colorectal cancer (Beskydy endoscopic workshop, Frýdek-Místek 2007), Extracolonic manifestations of FAP (National congress of gastroenterology, Brno 2008; Clinical cases in gastroenterology, Praha 2009; Congress of Czech society of gastroenterology, Praha 2009; Brno oncologic days, Brno 2010), FAP registries (Hradec gastroenterology and hepatology days, Hradec Králové 2009), FAP registry - single centre results (Hradec gastroenterology and hepatology days, Hradec Králové 2016). Single centre results from FAP register concerning duodenal involvement were presented at Digestive disease week in USA in 2010(4). FAP working group organized several symposiums dedicated to hereditary gastrointestinal cancers (Hereditary cancer syndromes, Educational and discussion days, Karlovy Vary 2010; FAP - indication for colectomy as an interdisciplinary task, Hradec gastroenterology and hepatology days, Hradec Králové 2014; Hereditary cancers of gastrointestinal tract, National congress of gastroenterology, Praha 2015).

Educational activities towards patients and their families were an additional task of the working group: Instruction leaflet for patients and their families were prepared in 2010 by Assoc. prof. Václav Jirásek and geneticist Jaroslav Kotlas, M.D. (5). Web pages with internet discussion forum for patients ran since 2010 on www.polyposy.cz (6).

\section{PRESENT AND FUTURE OF FAP REGISTRATION IN CZECH REPUBLIC}

Presentation of single centre results on abovementioned national gastroenterology meetings in 2015-16 represented the maximum achievable with existing register format with limited participation. Thus when Ministry of Health of Czech Republic announced National action plan for rare diseases, we claimed for this grant on the platform of Czech Society of Gastroenterology as a part of Czech Medical Association of J. E. Purkyně. Priority 3b of the Developing project is dedicated to generation and run of registries of rare diseases. Administration of the database came back under the wings of Institute of Biostatistics and Analysis of Masaryk University (IBA spin-off), which is the major provider of database medical services in Czech Republic. Primary network was formed by 5 centres involved in care of FAP patients (Military University Hospital Prague, General University Hospital Prague, ISCARE centre Prague, Masaryk Memorial Cancer Institute Brno and Faculty hospital Hradec Králové). Resources were definitely allocated in August 2016 and enabled to innovate existing database structure, tune the online interface with active participation of all engaged centres. Simultaneously we applied for the same grant for 2017. Our long-term goal is sustainable cooperation within current platform, which will be able to run register and thus to fulfil all clinical tasks of registration process including generation of adequate long-term results.

\section{ACKNOWLEDGEMENTS}

Supported by Ministry of Health of Czech Republic: Database for register of FAP No. OZS/42/4142/2016. 


\section{REFERENCES}

1. Bulow $S$, Berk T, Neale K. The history of familial adenomatous polyposis. Fam Cancer 2006; 5(3): 213-20.

2. Barrow P, Khan M, Lalloo F, Evans DG, Hill J. Systematic review of the impact of registration and screening on colorectal cancer incidence and mortality in familial adenomatous polyposis and Lynch syndrome. Br J Surg 2013 Dec; 100(13): 1719-31.

3. InSiGHT. International society for gastrointestinal hereditary tumours. [cited 2016 Dec 15]; Available from: https://www.insight -group.org.
4. Cyrany J, Rejchrt S, Kopacova M, Tycova V, Bures J. W1602: Duodenal adenomatosis in patients with familial adenomatous polyposis endoscopic diagnosis and therapy. Gastrointest Endosc 2010; 71(5): AB369-70.

5. Jirasek V, Kotlas J. Desatero pro pacienty s FAP [cited 2016 Dec 15]: Available from: http://www.kolonoskopie.cz/odborne/desatero -pro-pacienty-s-fap.aspx.

6. Cyrany J. Diskuse na téma FAP. [cited 2016 Dec 15]; Available from: http://www.kolonoskopie.cz/poradna-pro-pacienty/diskuse-na -tema-fap. 